Journal of Applied Pharmaceutical Science Vol. 5 (08), pp. 173-181, August, 2015

Available online at http://www.japsonline.com

DOI: $10.7324 / \mathrm{JAPS} .2015 .50827$

ISSN 2231-3354 (cc) EY-NC-SA

\title{
An insight of pharmacognostic study and phytopharmacology of Aquilaria agallocha
}

Janey Alam, Mohd. Mujahid, Badruddeen, Md. Azizur Rahman, Juber Akhtar, Mohmmad Khalid, Yasmeen Jahan, Abdul Basit, Akhlaque Khan, Mohd Shawwal, Shoiab Shadab Iqbal

Faculty of Pharmacy, Integral University, Lucknow-226026, India.

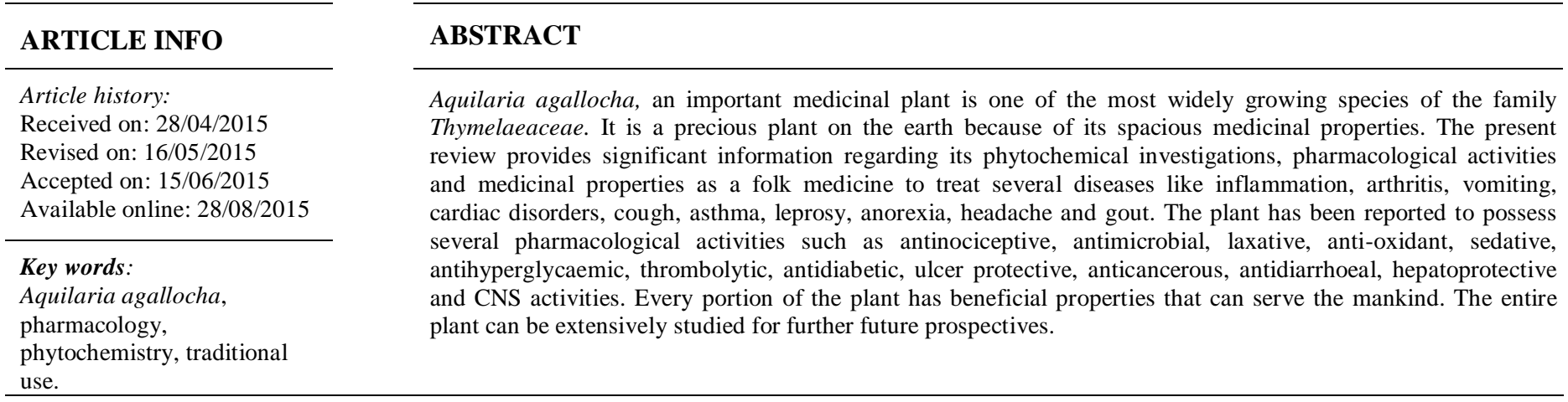

\section{INTRODUCTION}

In the last few decades, herbal products and dietary supplements are now widely available and considered complementary tools for health promotion. There is an exponential growth in the field of herbal medicine, getting the popularization in developing and developed countries owing to its natural source and lower side effects (Brahmachari, 2001).

Agar wood's use as a medicinal product has been recorded in the Sahih Muslim which dates back to approximately the eighth century and in the Ayurvedic medicinal text the Susruta Samhita (Chakarbarty et al., 1994; Fratkin, 1994).

In developing countries, a huge number of the population depends on traditional system and their armamentarium of medicinal plants in sequence of health care

* Corresponding Author

Mohd. Mujahid, Faculty of Pharmacy, Integral University, Lucknow, UP-226026, India.Email: mujahidiu@gmail.com profession. Nowadays, modern system of medicine can exist day by day and herbal systems of medicine have maintained their popularity for historical and cultural reasons (Rai, 2005).

Aquilaria agallocha belonging to the family Thymelaeacea is known as Gaharu in Indonesia and Malaysia, Aloewood in Hong kong, Mai Kritsana in Thai, Mai ketsana in Laos, Chengxiang in China, Shajarat-al-oudh in Arabic. It is also known as Agarwood, heartwood aloewood or eaglewood in English, Agar in Hindi, Oodh in Urdu, Aguru in Sanskrit, Sasi or Sashi in Assamese (Panda, 2009).

This plant is wild in Himalayan region, Assam, Tamil and East India. It grows at an altitude of 700-1400 m. It is very commonly cultivated in the wild of Assam (Tamuli et al., 2002b), East India and Bangladesh, other parts of south East Asia. It is also cultivated in China, Hong Kong, Indonesia, Sri Lanka and Tibet (Rahman and Khisa, 1984). Agarwood whole plant, and stem cuttings of one week, 6 months, 20 months old Agarwood have been shown in Figure 1. 

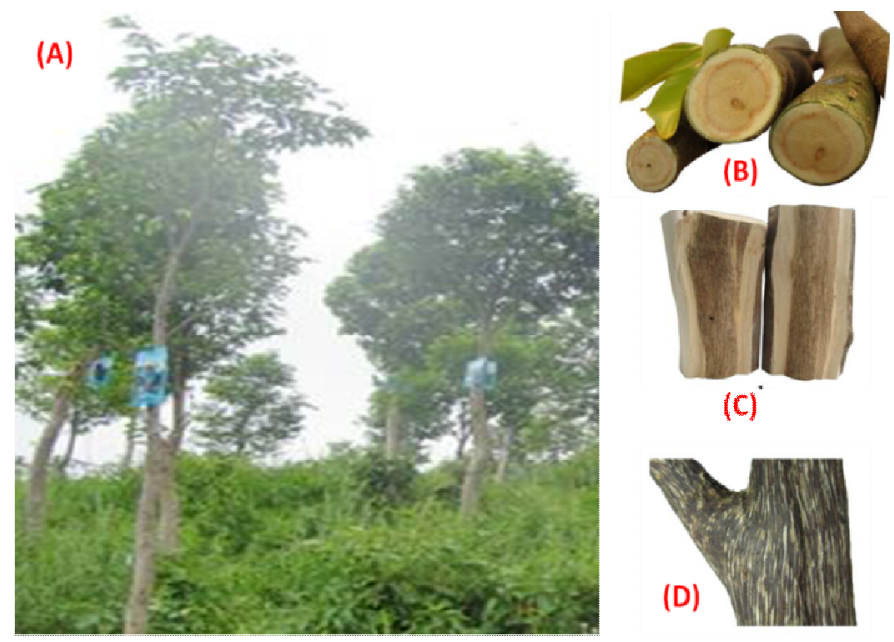

(C)

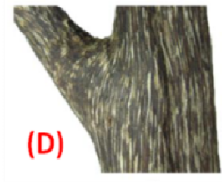

Fig. 1: (A) Whole plant of Agarwood, (B) One week Agarwood, (C) 6 months Agarwood, (D) 20 months Agarwood.

\section{TRADITIONAL USES}

Agarwood has been used for diverse purposes throughout the world for thousands of years. Its use has been reported in Ayurvedic, Tibetan and traditional East-Asian medical practice, including Shahih Muslim and Susruta Samhita (Chakrabarty et al., 1994; Fratkin, 1994). Its use as a perfume has been recorded in the Old Testament. Agarwood incense has been burned to produce a pleasant aroma for centuries, on important religious ceremonies, by Buddhists, Hindus and Muslims (Ng and Azmi, 1997). From the religious and sacred perspective mentioned several times in both the Bible and Islamic Hadith (spoken traditions of the Prophet Muhammad S.A.W), and also used in a variety of religious ceremonies ranging from Islamic prayer burial observances, to Buddhist rituals from Vietnam, Japan, China and Taiwan. In Arab society, aloeswood is highly prized and burned for guests as a sign of respect and in Japan aloeswood is used in the ancient koh doh or "listening to incense" ceremony (Burfield et al., 2005). Traditionally, the leaves, bark and root of the heartwood of Aquilaria agallocha are used for their medicinal properties such as acrid, anodyne, aphrodisiac, aromatic, astringent, bitter, cardiotonic, carminative, stimulant and fragrant. It is also used as mouth freshener, carminative and appetizer and relieves itching in pruritus. Agar wood powder is to given in loss of appetite and other digestive ailments. It improves blood circulation. It reduces cough and helps in bronchitis and asthma. Because of its cooling effect, Agar wood is used in fevers associated with chills, both internally and externally. Oil massage with Agar wood oil is effective in rigors in fevers. It may be used to treat toothache, colic pain, severe headache and pains during the pregnancy (Burfield $e t$ al., 2005).

\section{PHYTOCHEMISTRY}

Agar is considered to be a pathological product produced by fungal invasion of the host (Qi Shu-Yuan et al., 1992). Since 1938, few workers have been studying about agar formation and reported the agar zones to be associated with mold and decay fungi
(Bose, 1938; Bhattacharyya et al., 1952; Jalaluddin, 1977; Venkataramanan et al., 1985; Beniwal, 1989; Tamuli et al., 2000ab; Mitra and Gogoi, 2001). Among different fungal species reported to be associated with agar zones, few could exhibit pathogenesis with the development of disease symptoms while others seem to be of saprophytic nature in different ecogeographical conditions. Studies on the oil of infected $A$. agallocha has made by various workers (Maheshwari et al., 1963; Varma et al., 1965; Paknikar and Naik, 1975; Thomas and Ozainne, 1976; Pant and Rastogi, 1980; Bhandari et al., 1982; Nagashima et al., 1983; Ishihara et al., 1991, 1993). Maheshwari et al., (1963) isolated three new sesquiterpenic furanoids of the selinane group from agarwood oil obtained from the fungus infected plant and their structures and absolute configurations were determined by degradative studies and physical measurements. Varma et al., (1965) examined that degradative studies and physical measurements supported by an unambiguous synthesis of the derived ketone have led to the assignment of a novel spiroskeleton to agarospirol, a sesquiterpene alcohol isolated from the essential oil of infected agarwood. Paknikar and Naik (1975) reported that on hydrogenation of $\alpha$-agarofuran and $\beta$-agarofuran the same dihydroagarofuran was obtained. Thomas and Ozainne (1976) reported some naturally occurring dihydroagarofuran and isodihydroagarofuran and unequivocally shown that the dihydroagarofuran is found indeed dihydro- $\beta$-agarofuran and isodihydroagarofuran indeed isodihydro- $\beta$-agarofuran; two separate compounds. Pant and Rastogi (1980) and Bhandari et al., (1982) isolated a new sesquiterpene, agarol and a couinarinolignan, aquillochin respectively from the oil of Agarwood. Nagashima et al., (1983) further characterized the presence of two more sesquiterpene alcohols jinkohol II and jinkoheremol from the Indonesian Agarwood oil. Nakanishi et al., (1984) again reported that a benzene extract of an Indonesian sample of 'Jinkoh' Agarwood is found to contain $\alpha$-agarofuran, 10epi- $\gamma$-eudesmol and oxoagarospirol. Ishihara et al., (1991) characterized seven new sesquiterpenes based on the guaiane skeleton in a sample of Agarwood oil. Five new eudesmane sesquiterpenes and three other compounds were further characterized by Ishihara et al., (1993) in a sample of Agarwood extract produced in the laboratory from A. agallocha of Vietnamese origin. Vesicular-arbuscular myccorhizal association in the tree species and changes in amino acid composition due to pathogenesis were also studied by Tamuli et al., (2002a, 2002b). Tamuli et al., (2005) investigated the difference in composition of oils obtained from healthy, naturally infected and artificially eaglewood. This investigation showed a marked difference in the oil compositions among the treatments with regards to their quality. Valerianol (3.0\%) and tetradecanoic acid (7.1\%) contents were recorded higher in the oils of naturally infected plants than in that of healthy ones $(0.1 \%$ and $6.9 \%$ respectively). Pentedecanoic acid is totally absent in the oils of healthy plants, whereas it was found in a greater amount $(6.8 \%)$ in the oil of naturally infected plants. In contrast, dodecanoic acid (3.1\%), pentedecanoic acid $(6.2 \%)$, hexadecanoic acid (31.5\%) and octadecanoic acid were 
found in the oils of healthy plants, while the oils obtained from naturally infected plants contained lower amounts of these components $(2.3 \%, 4.8 \%, 20.0 \%$ and $1.0 \%$ respectively). Yoneda et al., (1984) identified the list of the major sesquiterpenes from $A$. agallocha including agarofuran $(0.6 \%)$, norketoagarofuran $(0.6 \%)$, agarspirol (4.7\%), jinkoeremol (4.0\%), kusunol (2.9\%), dihydrokaranone $(2.4 \%)$, and oxoagarospirol $(5.8 \%)$, and also isolated agarofuran, agarospirol (7.2\%), jinkohol (5.2\%), jinkoeremol $(3.7 \%)$, kusunol $(3.4 \%)$ and oxoagarospirol $(3.1 \%)$. From their findings the scientist concluded that Aquilaria agallocha exclusively contains norketoagarofuran and dihydrokaranone.

The presence of benzylacetone, $p$ methoxybenzylacetone, anisic acid and $\beta$-agarofuran as well as the sesquiterpenes baimuxinic acid, baimuxinal, baimuxinol, dehydrobaimuxinol, isobaimuxinol were confirmed (Yang et al., 1989 \& 1990). Battacharrya et al., (1959 \& 1965) reported that the presence of eight sesquiterpenes contained agarol and agarospirol together with $\alpha$ - and $\beta$ - agarofuran. Naf et al., (1992 \& $1995)$ reported $\beta$-agarofuran, vetispira-2(11), 6(14)-dien-7-ol, dihydrokaranone and valerianol as chief constituents of Indian Agarwood oil in fresh agarwood oil distilled from freshly Aquilaria agallocha (Indian wood). Alkhathlan et al., (2005) reported chromone together with two known 2-(2-phenylethyl)$4 H$-chromen-4-one derivatives from the acetone extract of the Agarwood of the Cambodian origin (A. agallocha).
Alkhathlan et al., (2005) reported diterpenoid compound from Agarwood. Bhandari et al., (1982) confirmed the presence of coumarinolignan from Aquilaria agallocha. Phytochemical constituents originating from the Aquilaria agallocha are Agarol (Jain and Battacharrya, 1959; Gunasekera et al., 1981), Aquillochin (Bhandari et al., 1982); Agarospiranes (sesquiterpines): Agarospirol, Baimuxinal, Baimuxinic acid (Yang et al., 1983; Verma et al., 1965), Vetaspira-2(11), 6(14)-dien-7-ol, Vetaspira-2(11), 6-dien-14-al, 2, 14-Epoxyvestispir-6-ene, 2, 14 Epoxyvestipir-6(14),7-diene (Naf et al., 1995), 11Hydroxyspirovetiv-1(10)-en-2-one (Ueda et al., 2006); Agarofurans (sesquiterpines): Baimuxifuranic acid (Yang et al., 1992), Norketoagarofuran, Dihyro-3,4-dihydroxyagarofuran, Dihydroagarofuran, Dihydro-4-hydroxyagarofuran, $\alpha$-agarofuran, $\beta$-agarofuran, (Maheshwari et al.,1963), Epoxy- $\beta$-agarofuran (Naf et al., 1993), Selina 3,11dien14al, Selina4,11dien14oic acid, Dehydrojinkoheremol, neopetasane (Ishara et al., 1993). The compounds isolated from the plant Aquilaria agallocha have been shown in Figure 2. Phytoconstituents of the plant is helpful in the discovery of new therapeutic agent as well as new sources of economic materials like oil, resins and gums. The most remarkable bioactive constituents of Agarwood are alkaloids, saponins, steroids, terpenoids, tannins, flavonoids and phenolic compounds (Satapathy et al., 2009). Phytochemical composition of different extracts from leaf and bark of A. Agallocha have been shown in Table 1.

Table 1 Phytochemical composition of different extracts from leaf and bark of A. Agallocha (Khalil et al., 2013)

\begin{tabular}{|c|c|c|c|c|c|}
\hline Phytochemicals & MEAAB & AEAAB & MEAAL & AEAAL & Result \\
\hline Alkaloid & +++ & + & ++ & ++ & + \\
\hline Anthroquinone & ++ & + & +++ & + & + \\
\hline Fixed oil and fats & ++ & + & + & ++ & + \\
\hline Glycoside & ++ & + & ++ & ++ & + \\
\hline Tannin & ++ & ++ & ++ & + & + \\
\hline Triterpenoids & +++ & +++ & ++ & ++ & + \\
\hline
\end{tabular}

$+=$ Low, $++=$ moderate, $+++=$ high, MEAAB $=$ methanolic extract of $A$. Agallocha bark, AEAAB = aqueous extract of $A$. Agallocha bark, MEAAL $=$ methanolic extract of A. Agallocha leaf, AEAAL = aqueous extract of A. Agallocha leaf.

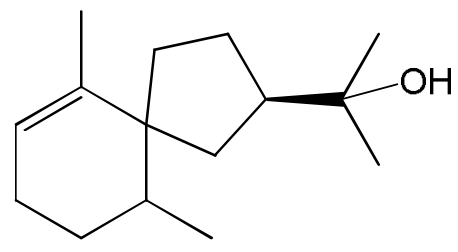

Agarospirol

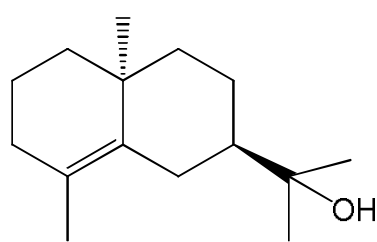

10-Epi-gamma-eudesmol

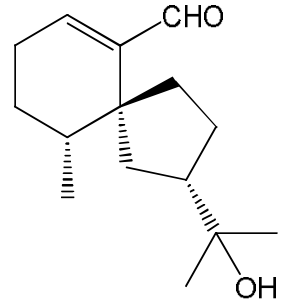

Oxo-agarospirol

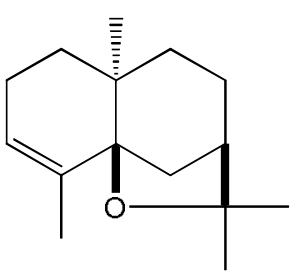

Alpha-agarofuran<smiles>C=C1CO[C@H]2C=C3CCC[C@H](C)[C@]3(C)C[C@H]12</smiles>

(3R, 7R, 9R, 10S)-9, 10dimethyl-6-methylene-4-

oxatricyclo|7.4.0.0|1-tridecene 2, 14-Epoxy-vetaspira-6-ene 2, 14-Epoxy-vetaspira-6(14), 7-diene
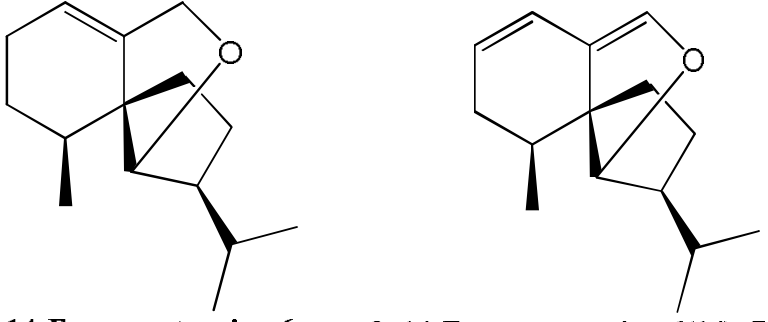

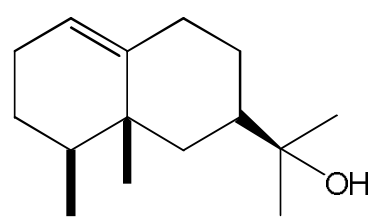

Jinkoh-eremol 


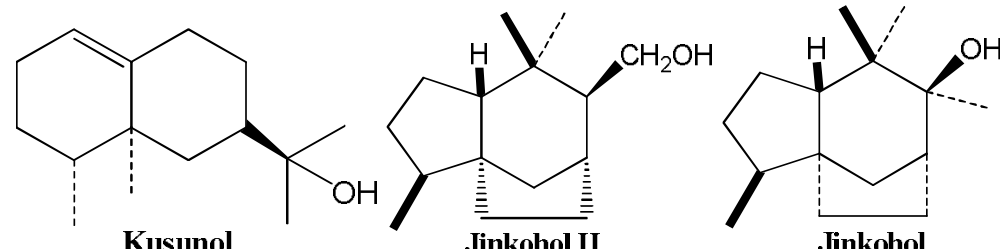<smiles>C=C1CCC[C@@H](C)[C@@]12CC[C@@H](C(C)(C)O)C2</smiles>

Kusunol

Jinkohol II

Isoagarospirol

Karanone
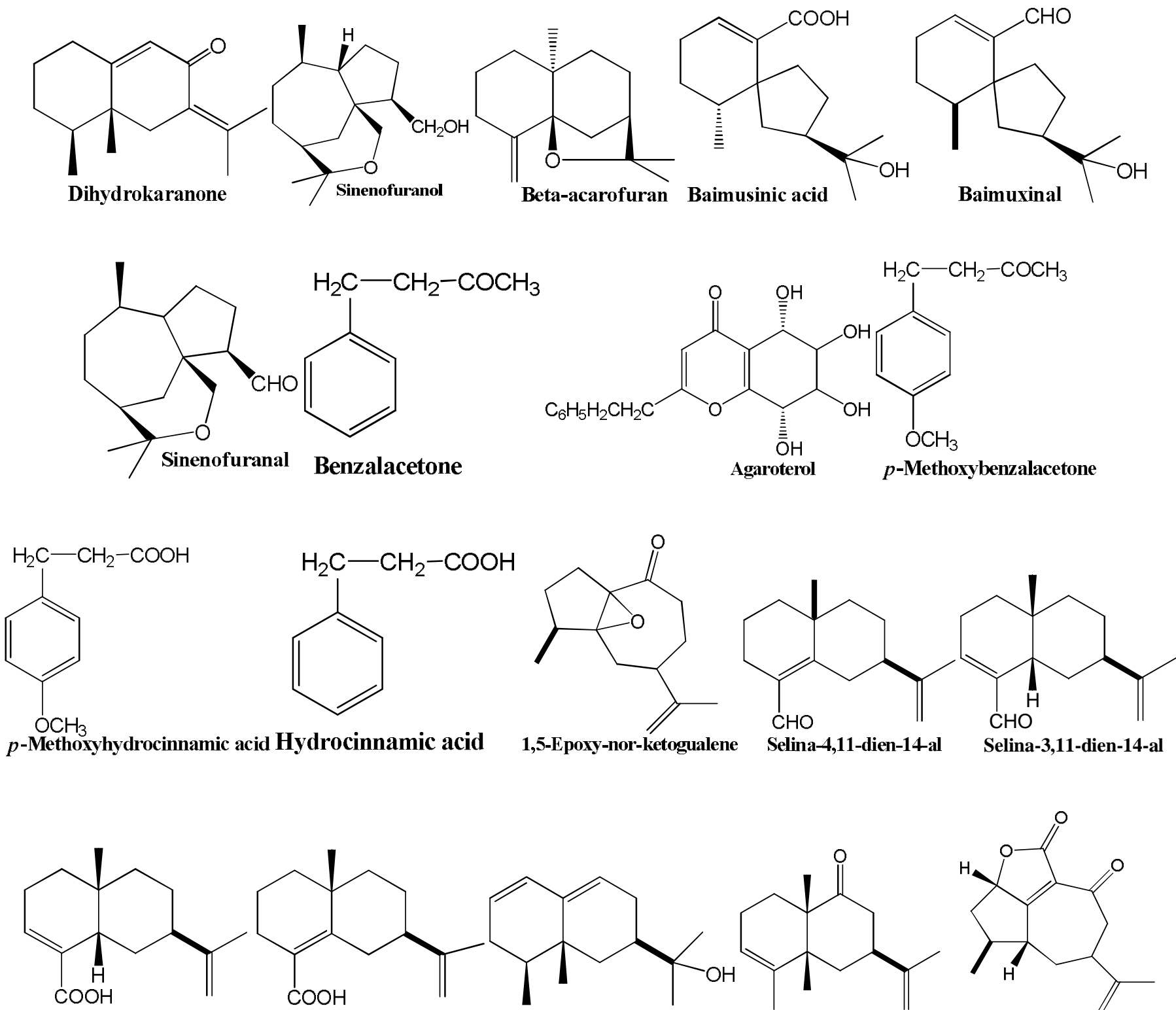

Selina-3,11-dien-14-oic acid Selina-1,4-dien-14-oic acid

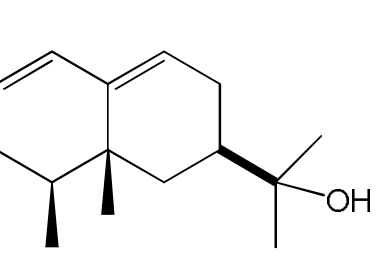

Dehydrojinkoh-eremol

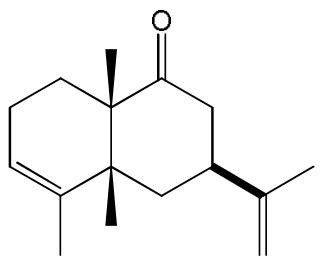

Selina-3,11-dien-9-one

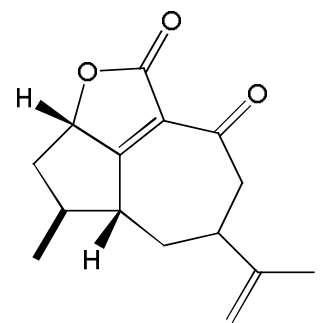

Guala-1[10],11-dien-15,2-olide<smiles>C=C(C)C1CCC(C=O)=C2CC[C@@H](C)[C@H]2C1</smiles>

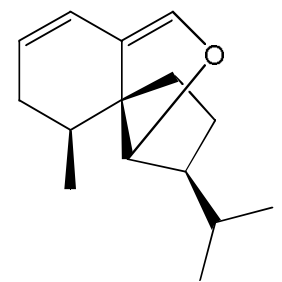

Fig. 2: The compounds isolated from the plant Aquilaria agallocha.

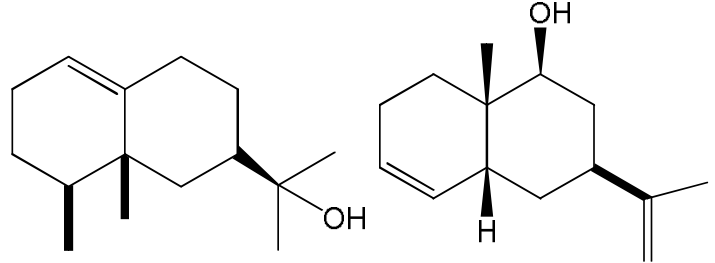

Selina-3,11-dien-9-ol

2,14-Epoxy-vetaspira-6[14],7-diene

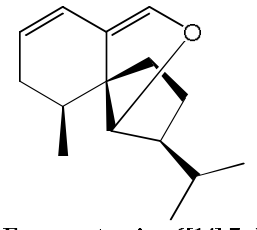




\section{PHARMACOLOGICAL ACTIVITIES}

\section{Antioxidant activity}

Miles and Grisham, (1994) investigated the antioxidant potential of ethyl acetate extract of the Aquilaria agallocha leaves (EAA) at different concentration of test compounds $(500 \mu \mathrm{g} / \mathrm{ml}$, $1000 \mu \mathrm{g} / \mathrm{ml}, 1500 \mu \mathrm{g} / \mathrm{ml}$ and $2000 \mu \mathrm{g} / \mathrm{ml})$. It was observed that EAA showed anti-oxidant effect at lower concentration range. However, the action was reversed at higher concentrations.

Sharma and Bhat, (2009) reported free radical scavenging activity of Aquilaria agallocha using 1,1-diphenyl-2picrylhydrazyl radicals (DPPH). The standard ascorbic acid at the concentration of $0.08-5 \mathrm{~g} / \mathrm{ml}$ diminished the DPPH oxidation by approximately 30-80\%. The anti-oxidative activities of ascorbic acid and Aquilaria agallocha extract (AAE) were found to have $\mathrm{IC}_{50}$ values equal to $2.19 \mathrm{~g} / \mathrm{ml}$ and $47.18 \mathrm{~g} / \mathrm{ml}$ respectively.

Miniyar et al., (2008) investigated the antioxidant activity of ethyl acetate extract of Aquilaria agallocha (EAA) in vitro at different concentrations for inhibitory effect on nitriteinduced oxidation of haemoglobin in human blood haemolysate. Result indicated a strong antioxidant effect of EAA in a concentration range of $500-3500 \mu \mathrm{g} / \mathrm{ml}$. However pro-oxidant activity was observed at higher concentrations of these compounds.

\section{Anti-diabetic Activity}

Omar, (2013) evaluate the effect of methanol and aqueous crude extracts of agarwood leaf in streptozocin induced diabetic rats with $20 \%$ glucose water consumption for 6 weeks, Orally administered crude methanolic and aqueous extract 250 to $500 \mathrm{mg} / \mathrm{kg}$ to the respective treatment groups and compared to metformin $(0.25 \mathrm{mg} / \mathrm{kg})$. The blood glucose level, body weight, glycosylated haemoglobin, muscle and liver glycogen, lipid profile status were measured and histopathology of pancreas was performed after 6 weeks of treatment and compared to the normal control.

In vitro experiment, the effects of the methanol and aqueous crude extract at concentration of $100 \mu \mathrm{g} / \mathrm{ml}$ to $1000 \mu \mathrm{g} / \mathrm{ml}$ are subjected to $\alpha$-glucisidase and amylase inhibitory activity, For comparable, Acarbose is used at same concentration as a standard. This expected result suggest that Malaysian agarwood leaves extract represent potential dietary supplements that may be useful for allowing flexibility in meal planning and automatically reduce the number of diabetic patients in worldwide population.

Aromdee et al., (2011) investigated anti-diabetic effect of methanol, water and hexane crude extracts of Aquilaria agallocha leaf on hyperglycemia in streptozocin induced diabetic rats were investigated. Only methanol and water extracts at dose of $1 \mathrm{~g} / \mathrm{kg}$ body weight lowered the fasting blood glucose levels 50 and $40 \%$ respectively. The results were comparable to $4 \mathrm{U} / \mathrm{kg}$ body weight of insulin $(73 \%)$. In vitro experiment, the effect of methanol and water extracts at the concentration of $10 \mu \mathrm{g} / \mathrm{ml}$ enhanced glucose uptake activity on rat adipocytes by $172 \pm 10$ and $176 \pm 21 \%$ of the normal control respectively. The glucose uptake enhancement activity is compared to $1.5 \mathrm{nM}$ insulin $(166 \pm 16 \%)$. The finding suggested that agarwood leaf is a promising potential anti-diabetic agent.

\section{Hepatoprotective activity}

Rahman et al., (2013) evaluated hepatoprotective effect of ethanolic extract of Aquilaria agallocha leaves (EEAA) induced by $\mathrm{CCl}_{4}$ hepatotoxicity in rat model by estimated serum hepatic enzyme levels and hisopathological study of liver tissues of rats. EEAA at dose $200 \mathrm{mg} / \mathrm{kg}$ and $400 \mathrm{mg} / \mathrm{kg}$ body weight administered per oral for 10 days in rats and compared with standard silymarin at dose $(100 \mathrm{mg} / \mathrm{kg})$ orally. The results showed significant decline in serum ALT, AST and ALP levels treated groups which increased due to $\mathrm{CCl}_{4}$ induced liver damage compared with standard drug. Histopathological study of liver tissues revealed hepatoprotective activity of EEAA.

\section{Anti-inflammatory activity}

Iyer, (1994) reported anti-inflammatory activity from the aqueous extract of Aquilaria agallocha leaves using carrageenan $0.1 \mathrm{ml}$ injection induced rat paw edema in mice. The paw volume of rat was measured at $0,1,2$ and 3 hours after carrageenan injection using a plethysmometer. The results expressed as significant changes in the paw volume from the basal value.

Suebsasana et al., (2009) tested anti-inflammatory activity from the extract of Aquilaria agallocha bark (AAE) at dose $(800 \mathrm{mg} / \mathrm{kg})$ or aspirin $(300 \mathrm{mg} / \mathrm{kg})$ administered per oral to treat with water (as the control). One hour after treatment, acute inflammation was produced by subcutaneous injection with $0.1 \mathrm{ml}$ of $1 \%$ carrageenan in the right paw of the rats. After carrageenan injection, the paw edema formation gradually increased within the $1^{\text {st }}$ hour for the control group, the maximum effect was reached over the duration of 3 hours. Animal treated with aspirin at the dose $300 \mathrm{mg} / \mathrm{kg}$ showed some swollen paws, and the paw volumes was significantly less than the control group after 2 or 3 hours.

Vakati et al., (2008) reported anti-inflammatory activity of Aquilaria agallocha oil (AAO) by carrageenan- induced edema in animal model and human red blood cell membrane stabilization method using $0.1 \mathrm{ml}$ of carrageenan locally injected into sub plantar region of left hind paw of rats. The potency of oil was compared with standard Diclofenac $(10 \mathrm{mg} / \mathrm{kg})$. The paw volume upto the ankle joint was measured at $0,1,2,3$ and 4 hours respectively after carrageenan injection using plethymometer. AAO showed significant reduction of edema in carrageenan induced paw edema model maximum at 3 hour for AAO at doses $50 \mathrm{mg} / \mathrm{kg}, 100 \mathrm{mg} / \mathrm{kg}$, p.o. and Diclofenac $10 \mathrm{mg} / \mathrm{kg}$, orally administered. The percentage reduction in paw volume $58.59 \%$, $62.11 \%$ and $68.94 \%$ respectably and membrane stabilizing action on human red blood cell membrane at the concentration of 100 , 250 and $500 \mathrm{mcg} / \mathrm{ml}$ shown $39.66 \%, 62.94 \%$ and $78.50 \%$ which was comparable with standard diclofenac.

Winter and Poster, (1957) reported anti-inflammatory activity of Aquilaria agallocha on rats by sub plantar injection of $.01 \mathrm{ml}$ solution of carrageenan in left hind paw of rats. After one 
hour oral administration of drugs induced edema in rats and right paw served as control group. Pretreatment with EAA (extract of Aquilaria agallocha) at the dose 50, 100 and $200 \mathrm{mg} / \mathrm{kg}$ ) significantly reduced edema at 1,2 and 3 hour after carrageenan injection. The reduction in edema produced by EAA at the dose (800 mg/kg, p.o.) was resembled to that of diclofenac $(10 \mathrm{mg} / \mathrm{kg}$, p.o.).

\section{Antipyretic activity}

Suebsasana et al., (2009) evaluated antipyretic activity on rats. Rats were trained to remain quiet in restriaint cage. The rectal temperature was recorded with $0.1{ }^{\circ} \mathrm{C}$ by inserting a lubricated digital thermometer into the rectum of each animal. After measuring the basal temperature and induced by a subcutaneous injection of a pyrogenic dose of Baker's yeast (135 $\mathrm{kg} / \mathrm{mg}$ ), significantly increase in the rectal temperature was recorded $3 \mathrm{~h}$ after induction. The animal treated with methanolic extract of Aquilaria agallocha leaves showed no antipyretic effect on the animal.

\section{Analgesic activity}

Suebsasana et al., (2009) tested analgesic activity on mice for the reaction time by placing them on a hot plate that was thermostatically maintained at $50^{\circ} \mathrm{C}$ with a four-wall plexi-glass container, confining the animals on the hot plate. Time that each mice spent on the hot plate (until it licked or jumped in response to pain) was recorded as the reaction time. The cut-off time of the test was set at $30 \mathrm{~s}$ in order to prevent tissue damage. The result of the study demonstrated that it possess analgesic activity.

D'Amour and Smith, (1941) screened analgesic activity after oral administration of extract or vehicle or standard. The tail flick latency was assessed at $0,1,2$, and $3 \mathrm{~h}$ by analgesiometer. The site of application of radient heat in the tail was measured at $2.5 \mathrm{~cm}$ from the root of the tail. The cut off time was fixed 15 second to avoid any tissue damage. The strength of current passed through naked nichrome wire kept constant at 4 amps. The extract of Aquilaria agallocha had confirmed significant analgesic effect.

Khalil et al., (2013) reported analgesic activity of ethanolic extract of Aquilaria agallocha leaves in mice using acetic acid induced writhing method and also reported to treat toothache, colic, severe headache, rheumatism and pains during pregnancy. It was clearly shown that the ethanolic extract of Aquilaria agallocha possess analgesic activity.

Chitre et al., (2007) investigated analgesic activity of the ethyl acetate extract of Aquilaria agallocha wood in mice u88sing aqueous acetic acid induced writhing by administering it at the dose of $10 \mathrm{ml} / \mathrm{kg}$ intraperitoneally (i.p.) after $1 \mathrm{~h}$ of oral administration of extracts. The mice placed in the observation chambers and after five minutes allowed to elapse. The number of writhes was counted at five min interval for next $30 \mathrm{~min}$. A remarkable reduction in number of writhes by treatment as compared to vehicle treated animals observed indicating positive analgesic response. Hanskaar and Hole, (1987) and Gorski et al.,
(1993) described analgesic activity of ethyl acetate extract of Aquilaria agallocha by formalin induced paw licking in mice. The formalin test possess two distinctive phases, which possibly reflecting different type of pain. Mice treated orally with ethyl acetate extract of Aquilaria agallocha $(50,100$ or $200 \mathrm{mg} / \mathrm{kg}$ ) or $2 \%$ Tween 80 solution in water or diclofenac solution $(10 \mathrm{mg} / \mathrm{kg})$. After $1 \mathrm{~h}, 20 \mu \mathrm{l}$ of $1 \%$ formalin was injected subcutaneously under the dorsal surface of hind paw. Mice were placed in the observation chambers. The number of licks was counted till $5 \mathrm{~min}$ (early phase) to next $30 \mathrm{~min}$ (latter phase) after formalin injection. The early phase had shown neurogenic pain while latter phase represented inflammation. After treatment and as compared with normal control group, animals showed good analgesic response.

\section{Antihistaminic activity}

Kim et al., (1997) reported the effect of the aqueous extract of Aquilaria agallocha leaves on the immediate hypersensitivity reactions. The extract showed inhibitory effects on passive cutaneously anaphylaxis induced by compound 48/80, and histamine release from rat peritoneal mast cell (RPMC). The morphological examination also clearly showed that the extract prevented the degranulation of RPMC in rats. The level of compound 48/80 induced intracellular cAMP in RPMC, when the extract added significantly enhanced about 8 -fold at 10 compared with that of basal cells. The result described as that the aqueous extract of Aquilaria agallocha inhibited the immediate hypersensitivity reaction by inhibition of histamine release from mast cell.

\section{Laxative effect}

Hara et al., (2008) reported the laxative effect of acetone extract of Aquilaria agallocha leaves measured by counting the stool frequency and stool weight. An acetone extract of Aquilaria agallocha leaves (at a dose of $1000 \mathrm{mg} / \mathrm{kg}$, p.o.) induced significant increase (up to 2-3 times the control value) in stool frequency and weight. However, a lower dose of acetone extract (100 or $300 \mathrm{mg} / \mathrm{kg}$, p.o.) did not induce any significant effect. But, higher dose of acetone extract $(1000 \mathrm{mg} / \mathrm{kg}$, p.o.) had a laxative effect on mice.

\section{Anti-bacterial activity}

Rahman et al., (2013) investigated antibacterial activity of Aquilaria agallocha oil and Citrullus lanatus seed oil by agar well diffusion method and compared with standard ciprofloxacin $(10 \mathrm{mcg} / \mathrm{ml})$ The test organisms used were Escherichia coli, Enterococcus faecalis, Staphylococcus aureus, pseudomonas aeruginosa. From the study, it was found that both had the antibacterial activity. The citrullus oil posses more antibacterial activity than Aquilaria agallocha oil.

\section{Antimicrobial activity}

Manasi et al., (2008) reported the aqueous and methanol extracts along with of dry powder of leaf and bark of Aquilaria 
agallocha for antimicrobial activity against pathogenic bacteria such as Shigella flexneri, bacillus brevis, yeast, dermatophytes and helminths by a disk-diffusion method. Anti-microbial activity was performed for various varieties of Aquilaria agallocha leaves. All the varieties were investigated against pathogenic microbes Bacillus cereus, Candada albicans, Streptococcus faecalis, Staphylococcus aureus, Pseudomonas aeruginosa, E. coli and Aspergillus niger. The aqueous extract from the leaves inhibited the growth of Pseudomonas aeruginosa and Staphylococcus aureus.

\section{Central nervous system (CNS) activity}

Okugawa et al., (1993) and Okugawa et al.,(1994) investigated alteration of brain monoamines (norepinephrine, dopamine and serotonin) and EEG wave in Alzheimer's disease in rats for ethanolic extract of Aquilaria agallocha leaves. Treatment with Aquilaria agallocha leaves extract restored the monoamine levels of brain regions to near control levels. The agarospiral and Jinkoh-eremol from Aquilaria agallocha injected by peritoneal and intracereboventricular route exerted beneficial effect on the central nervous system and diminished both methamphetamine and apomorphine induced spontaneous locomotion in the mice.

\section{Sedative effect}

Takemoto et al., (2008) reported sedative activity of Agarwood oil using a system of spontaneous vapour administration. It was found to have the sedative effect in mice. The volatile principles benzylacetone, $\alpha$-gurjunene and calarene obtained from it were also tested in mice which reproduced the result of the oil. It was found that the effective dose of the components was lower than their actual content in the oil.

\section{Anxiolytic activity}

Alla et al., (2007) described the axiolytic activity in mice with the EPM (Elevated Plus-Maze Test) for alcoholic extract of Aquilaria agallocha (AEAA). The lower dose of AEAA (30 $\mathrm{mg} / \mathrm{kg}$, p.o.) did not exhibited any significant effect on number of entries in both open and closed arms. But the medium and high doses $(100 \& 300 \mathrm{mg} / \mathrm{kg})$ of AEAA significantly increased open arm entries, time spent in open arm with decrease in closed arm entries and time spent in closed arm. However, AEAA and diazepam did not affect the total entries during the test period.

\section{Anti-convulsant activity}

Alla et al., (2007) investigated the anti-convulsion activity of alcoholic extract of Aquilaria agallocha (AEAA) using PTZ (Pentylene tetrazole) to induced convulsion. AEAA at lower dose $(30 \mathrm{mg} / \mathrm{kg})$ did not offered any significant anti-convulsion effect, medium dose $(100 \mathrm{mg} / \mathrm{kg})$ had significantly altered onset of clonus but not onset of tonic seizures, but higher dose shown a significant anticonvulsion effect by increasing latencyof clonus, onset of tonic seizures and declined mortality of mice, $33 \%$ of animals were survived with AEAA at a dose of $(100 \mathrm{mg} / \mathrm{kg})$ and $67 \%$ survived with $(300 \mathrm{mg} / \mathrm{kg})$.

\section{DISCUSSION AND CONCLUSION}

For the decades, natural herbs have been a source of remedy and drugs lead (Brahmachari, 2001). Natural products condition the inspiration for sorts of strategies used in the diversity oriented synthesis of the novel small moiety libraries. An enhancing body of the evidence supports the effectiveness of these planning of the operation for recognizing new biologically active moiety (Khare, 2007). Aquilaria agallocha, an important medicinal plant is most costly and precious things on the earth and most widely cultivated species of the family Thymeleaceace. Whole plant has been used for human medication. Insight of literature review on this medicinal plant unambiguity elaborate its various traditional uses as anti-asthmatic, anti-inflammatory, antidiarrhoeal, aphrodisiac, aromatic, astringent, bitter, cardiotonic, carminative, stimulant and fragrant. Oil massage with Agar wood oil is effective in rigors in fevers, and also used in perfumes, the woods burn for fragrance and used in various cosmetic formulations (Hayder et al., 2005). Pharmacologically reported various activities includes antioxidant, hepatoprotective, antidiabetic, anti-inflammatory, analgesics, sedative, central nervous system, anti-pyretic, anti-bacterials, laxative, antihistaminic and anti-microbial activities. Phytochemically, it is helpful in the discovery of new therapeutic agent as well as new sources of economic materials like oil, resins and gums. The most remarkable bioactive constituents are alkaloids, saponins, steroids, terpenoids, tannins, flavonoids and phenol compounds. $A$. agallocha is including agarofuran $0.6 \%$, norketoagarofuran $0.6 \%$, agarspirol $4.7 \%$, jinkoeremol $4.0 \%$, kusunol $2.9 \%$, dihydrokaranone $2.4 \%$, and oxoagarospirol $5.8 \%$ and also isolate and identified agarofuran, agarospirol $7.2 \%$, jinkohol $5.2 \%$, jinkoeremol $3.7 \%$, kusunol $3.4 \%$ and oxoagarospirol $3.1 \%$. The present review summarizes few significant pharmacological studies on Aquilaria agallocha and phytochemical investigation and isolated chief chemical constituents from them, which can be evaluated to achieve lead molecules in the search of novel herbal drugs.

\section{ACKNOWLEDGEMENT}

The authors express their sincere thanks to Faculty of Pharmacy, Integral University, Lucknow to encourage them by its research atmosphere and its all valuable supports.

\section{REFERENCES}

Alkhathlan HZ, ALHazimi HM, ALDhalaan FS \& Mousa AA. Three 2(2phenylethyl) chromones and two terpenes from agarwood Natural Product Research, 2005; 19(4), 367- 372.

Alla T, Handral M, Nandakumar K, Venkatrao N, Shalam, Satyanaryana, Shantakumar SM. Anxiolytic and anticonvulsant activity of alcoholic extract of heartwood of Aquilaria agallocha roxb, (Thymelaeceae) in mice. Pharmacologyonline, 2007; 1: 564-572.

Aromdee C, Pranakhon R, Pannangpetch P. Antihyperglycemic activity of agarwood leaf extracts in STZ-induced diabetic rats and glucose uptake enhancement activity in rat adipocytes. Songklanakarin J. Sci. Technol, 2011; 33 (4), 405-410. 
Beniwal BS. Silvical characteristics of Aquilaria agallocha Roxb. Indian Forest, 1989; 115: 17-21.

Bhandari P, Pant P, \& Rastogi RP. Aquillochin, a coumarinolignan from Aquilaria agallocha. Phytochemistry, 1982; 21(8): 2147-2149.

Bhattacharyya B, Datta A, Baruah HK. On the formation and development of agaru in Aquilaria agallocha. Sci Cult, 1952; 18: 240- 41.

Bose SR. The nature of 'Agaru' formation. Sci Cult, 1938; 4: 89-

91.

Brahmachari UN. The role of science in recent progress of medicine. Current Science, 2001; 81(1): 15-16.

Burfield, Tony, Kirkham K. "The Agarwood Files." Cropwatch, 2005.

Chakrabarty K, Kumar A, Menon V. Trade in agarwood. TRAFFIC India and WWF India, 1994; New Delhi.

Chitre T, Bhutada P, Nandakumar K, Somni R, Miniyar P, Mundhana Y, Gore S and K. Analgesic and anti-inflammatory activity of heartwood of Aquilaria agallocha in laboratory animals, Pharmacologyonline, 2007; 1: 288-298

D'Amour FE, Smith DL. A method for determining loss of pain sensation. J.Pharm.Exp.Therap, 1941; 72, 74-79.

Fratkin J. Chinese herbal patent formulas: a practical guide. Shya Publications, Colorado, 1994

Gibson IAS. The role of fungi in the origin of oleoresin deposits (Agaru) in the wood of Aquillaria agallocha (Roxb.). Bano Biggyn Patrika, 1977; 6: 16-26.

Gorski, F, Correa CR, Filhe VC, Yunes RA, Calixto JB. Potent antinociceptive activity of hydroalcoholic extracts from Phyllanthus corcovadensis. J. Pharm. Pharmacol, 1993; 45, 1046-1049.

Gunasekera SP, Kinghorn DA, Cordell GA, Farnsworth NR. $J$ Nat. Prod. 1981; 44,569.

Hanskaar S, Hole K. The formalin test in mice: dissociation between inflammatory and non-inflammatory pain. Pain, 1987; 30, 103104.

Hara $\mathrm{H}$, Ise $\mathrm{Y}$, Morimoto $\mathrm{N}$, Shimazawa M, Ichihashi $\mathrm{K}$, Ohyama M, Iinuma M. Laxative effect of agar wood leaves and its mechanism. Scholars Journal of Applied Medical Sciences, 2008; 1: $335-$ 345 .

Hayder MAK, Rahman LM, Rahman MA. Experimental agar production project (in Bengali). Department of Forests, Ministry of Environment and Forest, Dhaka, 2005; pp 1-16.

Ishihara $M$, Tsuneya $T$, Suga $M$, Uneyama $K$. Three sesquiterpenes from agarwood Phytochemistry, 1991; 30, 563-566.

Ishihara M, Tsuneya T, Uneyama K. Fragrant sesquiterpenes from agarwood. Phytochemistry, 1993; 33: 1147-55.

Iyer SR. Indian Medicinal Plants, A compendium of 500species. Hyderabad, India: Orient Longman. International Journal of Basic Medical Sciences And Pharmacy, 2012; 2: 2049-2063.

Jafri MA, Jalis SM, Kalin J, Surender S. Hepatoprotective activity of leaves of Cassia occidentalis against paracetamol and ethyl alcohol intoxication in rats. Journal of Ethnopharmacology, 1999; 66: 355-361.

Jain TC., Battacharrya SC. Structure, stereochemistry and absolute configuration of agarol, a new sesquiterpene alcohol from agarwood oil. Tetrahedron Letters, 1959; 1(9),13-17.

Jalaluddin M. A useful pathological condition agarwood.Econ. Bot, 1977; 31: 222-24.

Khalil AS, Rahim AA, Taha KK, Abdallah KB. Characterization of Methanolic Extracts of Agar wood Leaves. Journal of Applied And Industrial Sciences, 2013; 1(3): 78-88.

Khare CP. Indian medicinal plants. Springer, 2007; 422-423.

Kim YC, Lee EH, Lee YM, Kim KH, Song B, Lee EJ, Kim HM. Effect of the aqueous extract of Aquilaria agallocha stems on the immediate hypersensitivity reactions. Journal of Ethnopharmacology, 1997; 1: 31-38.

Konishi T, Konoshima T, Shimada Y, Kiyosawa S. Six new 2(2-phenylethyl)chromones from Agarwood. Chemical \& Pharmaceutical Bulletin (Tokyo) 2002; 50(3): 419-422.
Maheshwari ML, Jain TC, Bates RB, Bhattacharyya SC. Terpenoids-xli: structure and absolute configuration of $\alpha$-agarofuran, agarofuran and dihydroagarofuran. Tetrahedron 1963; 19(6), 1079-1090.

Maheshwari ML, Varma KR, Bhattacharyya SC. TerpenoidsXLVII: structure and absolute configuration of norketoagarofuran, 4hydroxydihydroagarofuran, 3,4-dihydroxydihydroagarofuran and conversion of $\beta$-agarofuran to $\alpha$-agarofuran. Tetrahedron $1963 ; 19(10)$, $1519-1525$.

Manasi D, Jayanta KP, Prasanna PP, Phytochemical and antimicrobial screening of extracts of Aquilaria agallocha Roxb. African Journal of Biotechnology, 2008; 3531-3534.

Miles AM, Grisham MB. Antioxidant properties of aminosalicylates. Journal Green Pharmacy Information, 1994; 234: 555572.

Miniyar PB, Chitre HJ, Deuskar PS, Karve SS, Jain SK. Antioxidant activity of ethyl acetate extract of Aquilaria agallocha on nitrite induced methaemoglobin formation, International Journal of Green Pharmacology, 2008; 1: 116-117.

Mitra J, Gogoi P. Fungi associated with the diseased wood (agarwood/agaru) of Aquilaria agallocha Roxb. Proceedings of seminar on scope and dimension of agarplantation in NE region Ahmed M, Gogoi P, Ahmed GU, Hojai AATMA . India, 2001, pp 61-69.

Naf R, Velluz A, Brauchli \& Thommen W. Agarwood oil (Aquilaria agallocha Roxb.). Its composition and eight new valencane, eremophilane, vetispiranederivatives. Flav. FragJ, 1995; 10: 147-152.

Naf R, Velluz A, Busset N, Gaudin JM. New Norsesquiterpenoids with 10epiEudesmane Skeleton from Agarwood (Aquilaria agallocha Roxb.) Flav \& Frag J, 1992; 7(6): 295-298.

Naf R, Velluz A, Thommen W, Brauchli R. New Compounds Identified in Agarwood (Aquilaria agallocha Roxb.). Flavour \& Fragrance J 1993; 8(6): 307-313.

Nagashima T, Kawasaki I, Yoshida T, Nakanishi T, Yoneda K, Miura I.New Sesquiterpenoids from agarwood. Paper IXth International essential oil congress. Singapore, 1983, pp 12-16.

Nagashima T, Kawasaki I, Yoshida T, Nakanishi T, Yoneda K. 9th International Essential Oil Congress, Singapore, 1983; Vol. 3, p. 12.

$\mathrm{Ng} \mathrm{L}$, Azmi M. Trade in medicinal and aromatic plants in Malaysia Forest Research Institute of Malaysia (FRIM), Selangor Darul Ehsan, 1997; (1986-1996). Report No. 71.

Okugawa H, Ueda R, Matsumoto K, Kawanishi K, Kato A. Effect of agarwood on the Central Nervous System in mice. Planta Medica, 1993; 59: 32-36.

Omar NAM, Zulkifle NL, Tajudin SN. Antidiabetic activities of Malaysian Agarwood leaves extract, Conference on industry Academia joint initiatives in Biotechnology CIA, 2013; 5:7. Paknikar SK, Naik CG. Stereochemistry of dihydroagarofurans and evidence in support of the structure of 4,11- epoxy-ciseudesmane. Tet Lett. 1975; 15: 129394.

Panda H. Aromatic Plants Cultivation, Processing And Uses, National Institute Of Industrial, 2009; 8: p. 182.

Pant P \& Rastogi RP. Agarol, a new sesquiterpene from Aquilaria agallocha. Phytochemistry, 1980; 19(8): 1869-1870.

Qi Shu-Yuan, Lu Bi-Yau, Zhu Liang-Feng, Li Bao-Ling. Formation of oxoagarospirol in Aquilaria sinensis. Plant Physiol Commun, 1992; 28: 336-39.

Rahman H, Vakati K, Eswaraiah MC and Dutt AM. Evaluation of hepatoprotective activity of ethanolic extract of Aquilaria agallocha leaves (EEAA) against CCl4 induced hepatic damage in rat. Scholars Journal of Applied Medical Sciences, 2013; 1(1):9-12.

Rahman MA, Khisa SK. Agar production in agar tree by artificial inoculation and wounding, part-II, further evidences in favor of agar formation. Bono Biggyan Patrika, 1984; 9(1-2):57-63.

Rai J. Traditional uses, phytochemistry and pharmacological properties of Moringa oleifera plant: An overview. JK Science 2005; 7(3): 180-185.

Ratree P, Patchareewan P, Chantana A. Antihyperglycemic activity of agar wood leaf extracts in STZ-induced diabetic rats and glucose uptake enhancement activity in rat. Pakistan Journal Pharmacological Science, 2011; 405-410. 
Satapathy AK., Gunasekaran G, Sahoo SC, Kumar A, Rodriques PV. Corrosion inhibition by Justicia gendarussa plant extract in hydrochloric acid solution.Corrosion Science, 2009; 51, 2848-2856.

Sharma OP, Bhat TK.. DPPH antioxidant assay revisited. Food Chem. 2009; 113:1202-5.

Sharma SK. Antituberculosis drugs and hepatotoxicity. African Journal of Biotechnology 2004; 4: 167-170.

Suebsasana S, Pongnaratorn P, Sattayasai J, Arkaravichien T, Tiamkao S, Aromdee C. Analgesic, antipyretic, anti-inflammatory and toxic effects of andrographolide derivatives in experimental animals. Arch Pharm Res. 2009; 32:1191-200.

Takemoto H, Ito M, Shiraki T, Yagura T, Honda G. Sedative effects of vapour inhalation of agar wood oil and spikenard extract and identification of their active components. Journal of Natural Medical Science, 2008; 62: 41-46.

Tamuli P, Boruah P, Nath SC, Samanta R. Fungi from diseased agarwood tree (Aquilaria agallocha Roxb.): Two new records. Adv Forest Res India 2000a; 22: 182-87.

Tamuli P, Boruah P, Nath SC, Samanta R. Mycofloral study on the phyllosphere and soil of agarwood tree plantation.U.G.C. Sponsored seminar on conservation of biodiversity, Assam, 2000b; $\mathrm{p} 5$.

Tamuli P, Boruah P, Nath SC. Essential oil of eaglewood tree: A product of pathogenisis. J Essent Oil Res. 2005; 17: 601-04.

Tamuli P, Boruah P. Changes in amino acids in agarwood plant under pathological condition. Geobios. 2002a; 29: 241-43.

Tamuli P, Boruah P. Vesicular-arbuscular mycorrhizal (VAM) association of agarwood tree in Jorhat district of the Brahmaputra Valley. Indian Forest. 2002b; 128: 991-94.

Thomas AF, Ozainne M. The stereochemistry of the dihydroagarofurans. Tet Lett, 1976; 20: 1717-18. http://Bangladesh J Pharmacol 2009; 4: 24-28 dx.doi.org/ 10.1016/S0040-4039(00)92932-0

Ueda J -y, Imamura L, Tezuka Y, Tran QL, Tsuda M, Kadota S. Bioorg. Med. Chem, 2006; 14, 3571.

Vaidya ADB, Devasagayam TPA. Journal of Clinical Biochemistry and Nutrition, Phytochemistry, 2007; 41, 11.

Vakati K, Rahman H, Eswaraiah MC. In-vivo and In-Vitro Anti Inflammatory Activity of Aquilaria agallocha Oil, International Journal of Basic Medical Sciences and Pharmacy (IJBMSP) 2012; Vol. 2, (1) : 2049-4963.
Varma KR, Maheshwari ML, Bhattacharyya SC. The constitution of agarospisol a sesquiterpenoid with a new skeleton. Tetrahedron 1965; 21: 11538. http://dx.doi.org/10.1016/S0040-4020 (01)82208-0

Venkataramanan MN, Borthakur R, Singh HD. Occurrence of endotrophic myccorhizal fungus in agarwood plant Aquilaria agallocha Roxb. Curr Sci, 1985; 54: 928.

Winter CA, Poster CC, Effect of alternation in side chain up on anti-inflammatory and liver glycogen activities in hydrocortisone ester. J. Amer. Pharmacol. Soc, 1957; 46, 515-519.

Yagura T, Ito M, Kiuchi F, Honda G, Shimada Y. Four new 2 (2phenylethyl) chromone derivatives from the withered wood of Aquilaria sinensis. Chem PharmBull, 2003; 51(5): 560-564.

Yagura T, Shibayama N, Ito M, Kiuchi F \& Honda G. Three novel diepoxy tetrahydrochromones from agarwood artificially wounded by intentional wounding Tetrahedron Letters, 2005; 46(25): 4395-4398.

Yang JS, Chen YW. Studies on the constituents of Aquilaria sinensis (Lour.) Gilg. I. Isolation and structure elucidation of two new sesquiterpenes, baimuxinic acid and baimuxinal. Acta Pharmacologica Sinica 1983;18(3):191-198

Yang JS, Wang YL, Su YL. Baimuxifuranic acid,a new sesquiterpene from the volatile oil of Aquilaria sinensis (Lour.) Gilg [J]. Chinese Chemical Letters1992; 3(12): 983-984.

Yoneda K, Yamagata E, Nakanishi T, Nagashima T, Kawasaki I, Yoshida T, Mo Yoneda K. Sesquiterpenoids in Two Different kinds of Agarwood. Phytochem, 1984; 23(9): 2068-2069.

\section{How to cite this article:}

Janey Alam, Mohd. Mujahid, Badruddeen, Md. Azizur Rahman, Juber Akhtar, Mohmmad Khalid, Yasmeen Jahan, Abdul Basit, Akhlaque Khan, Mohd Shawwal, Shoiab Shadab Iqbal. An insight of pharmacognostic study and phytopharmacology of Aquilaria agallocha. J App Pharm Sci, 2015; 5 (08): 173-181. 